\title{
Corrigenda
}

Genome Research 28: 256-265 (2018)

\section{Corrigendum: Detecting differential copy number variation between groups of samples}

Craig B. Lowe, Nicelio Sanchez-Luege, Timothy R. Howes, Shannon D. Brady, Rhea R. Daugherty, Felicity C. Jones, Michael A. Bell, and David M. Kingsley

Due to a formatting error, Supplemental Table S4 in the above-mentioned article displayed incorrect gene identifiers as the closest transcription start site in column E. The revised Supplemental Table S4 has been posted online to reflect the correct gene identifiers. This error does not affect the analyses performed in this paper. The authors apologize for the inconvenience.

doi: $10.1101 /$ gr.237370.118

Genome Research 28: 145-158 (2018)

\author{
Corrigendum: Evolutionary expansion of DNA hypomethylation in the mammalian germline \\ genome \\ Jianghan Qu, Emily Hodges, Antoine Molaro, Pascal Gagneux, Matthew D. Dean, Gregory J. Hannon, \\ and Andrew D. Smith
}

The authors would like to correct the omission of a funding source in the Acknowledgments section which was inadvertently excluded from the initial publication of this article. The corrected text is as follows and has been updated online:

"This research was partially supported by National Institutes of Health grant R01 HG005238 to A.D.S. and National Institutes of Health grant R01 GM098536 to M.D.D."

The authors apologize for the inconvenience.

doi: $10.1101 /$ gr.236885.118

Genome Research 27: 38-52 (2017)

Corrigendum: A systematic comparison reveals substantial differences in chromosomal versus episomal encoding of enhancer activity

Fumitaka Inoue, Martin Kircher, Beth Martin, Gregory M. Cooper, Daniela M. Witten, Michael T. McManus, Nadav Ahituv, and Jay Shendure

The authors would like to correct the omission of Supplemental Files 1, 2, and 3 in the initial publication of this article. Please note that the Supplemental files have now been added to Supplemental Material online. The authors apologize for any confusion this may have caused. 


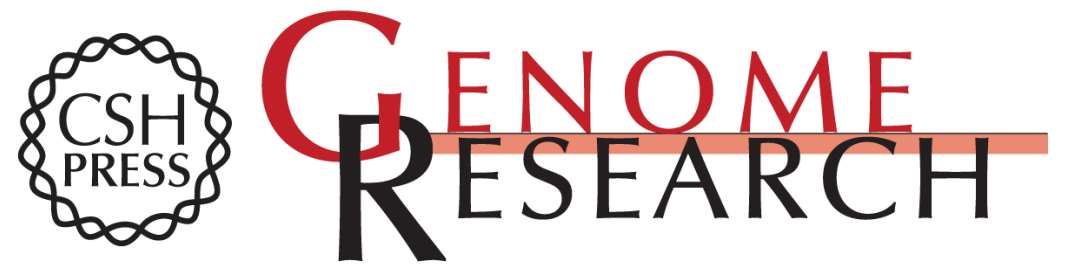

\section{Corrigendum: Evolutionary expansion of DNA hypomethylation in the mammalian germline genome}

Jianghan Qu, Emily Hodges, Antoine Molaro, et al.

Genome Res. 2018 28: 766.2

Access the most recent version at doi:10.1101/gr.236885.118

Related Content Evolutionary expansion of DNA hypomethylation in the mammalian germline genome

Jianghan Qu, Emily Hodges, Antoine Molaro, et al.

Genome Res. February , 2018 28: 145-158

Open Access Freely available online through the Genome Research Open Access option.

License

Email Alerting Receive free email alerts when new articles cite this article - sign up in the box at the Service top right corner of the article or click here.

\section{Affordable, Accurate} Sequencing.

To subscribe to Genome Research go to:

https://genome.cshlp.org/subscriptions 